\title{
PHK DAN PANDEMI COVID-19: SUATU TINJAUAN HUKUM BERDASARKAN UNDANG-UNDANG TENTANG KETENAGAKERJAAN DI INDONESIA
}

\author{
${ }^{1}$ Vicko Taniady, ${ }^{2}$ Novi Wahyu Riwayanti, ${ }^{3}$ Reni Putri Anggraeni, ${ }^{4}$ Ahmad Alveyn \\ Sulthony Ananda, ${ }^{5}$ Hari Sutra Disemadi \\ 1,2,3,4 Fakultas Huku, Universitas Jember, Jember, Indonesia \\ ${ }^{5}$ Fakultas Hukum, Universitas Internasional Batam, Batam, Indonesia \\ Email: taniadivicko5@gmail.com
}

\begin{abstract}
ABSTRAK
Sejak masuknya pandemi COVID-19 di Indonesia pada awal Maret 2020, perekonomian di Indonesia mengalami pertumbuhan negatif. Pertumbuhan negatif perekonomian berdampak pada pemutusan hubungan kerja (PHK) secara massal di banyak perusahaan. Tujuan penelitian ini adalah menganalisis pemutusan hubungan kerja (PHK) secara massal di tengah pandemi COVID-19 yang ditinjau berdasarkan perspektif Undang-Undang Ketenagakerjaan. Metode penelitian yang digunakan dalam penelitian ini adalah metode hukum normatif dengan mengutamakan data sekunder. Hasil Penelitian ini menunjukkan, pemutusan hubungan kerja yang dilakukan oleh banyak perusahaan memberikan dampak negatif bagi para pekerja. Terlebih dalam Pasal 151 ayat 1 Undang-Undang Nomor 13 Tahun 2003 tentang Ketenagakerjaan telah menegaskan bahwa pengusaha, buruh/pekerja, pemerintah dengan segala upaya harus mengusahakan agar jangan terjadi pemutusan hubungan kerja. Sehingga berdasarkan penelitian ini menunjukkan, pemutusan hubungan kerja ditengah pandemi COVID-19 bukanlah win-win solution.
\end{abstract}

Kata kunci : Pemutusan Hubungan Kerja; Ketenagakerjaan; COVID-19

\section{ABSTRACT}

Since the entry of the COVID-19 pandemic in Indonesia in early March 2020, the economy in Indonesia has experienced negative growth. Negative economic growth has resulted in mass layoffs (layoffs) in many companies. The purpose of this study is to analyze mass layoffs during the COVID-19 pandemic which is reviewed from the perspective of the Labor Law. The research method used in this reserach is the normative legal method by prioritizing secondary data. The results of this reserach indicate that termination of employment by many companies hurts workers. Especially in Article 151 paragraph 1 of Law Number 13 of 2003 concerning Manpower, it has been stated that employers, laborers/workers, the 
government must make every effort to prevent termination of employment. So based on this research it shows that laying off work during the COVID-19 pandemic is not a win-win solution.

Keywords : Work Termination; Employment; COVID-19

\section{Latar Belakang}

Indonesia merupakan negara hukum yang telah tertuang dalam Undang-Undang Dasar Negara Republik Indonesia Pasal 1 Ayat 3. Sejak dideklarasikannya Indonesia sebagai negara hukum, Indonesia memiliki kewajiban untuk menegakkan keadilan dan kemakmuran dalam masyarakat. Konsep negara hukum, sangat menjamin hak asasi manusia yang dimiliki oleh semua orang. Hal ini sejalan dengan pandangan Julius Stahl mengenai konsep Negara Hukum yang disebutnya dengan istilah 'rechtsstaat' yang mencakup empat elemen penting, yaitu adanya perlindungan hak asasi manusia, pembagian kekuasaan, pemerintahan berdasarkan undangundang dan adanya peradilan tata usaha negara (Muabezi, 2017).

Perlindungan para buruh dan tenaga kerja mendapatkan perhatian khusus dalam konsep negara hukum yang berkaitan dengan hak asasi manusia. Pasal 27 ayat 2 menyatakan bahwa "Tiap-tiap warga negara berhak atas pekerjaan dan penghidupan yang layak bagi kemanusiaan." Perlindungan buruh dan tenaga kerja juga tertuang dalam Pasal 28D Ayat 3 UUD NRI 1945, bahwa: "Setiap warga negara memiliki hak untuk bekerja dan mendapat imbalan serta perlakuan yang adil dan layak dalam hubungan kerja." Namun, ditengah jaminan perlindungan terhadap buruh dan tenaga kerja, terdapat permasalahan di dalamnya. Permasalahan buruh dan tenaga kerja bukanlah hal yang asing lagi ditelinga negara berkembang. Salah satu permasalahan tersebut adalah pemutusan hubungan kerja yang dilakukan oleh perusahaan di Indonesia secara sepihak (Hendrastomo, 2010). Berdasarkan Undang-Undang Nomor 13 Tahun 2003 tentang Ketenagakerjaan, pemutusan hubungan kerja adalah pengakhiran hubungan kerja karena suatu hal tertentu yang mengakibatkan berakhirnya hak dan kewajiban antara pekerja atau buruh dan pengusaha. Umar Kasim juga menyatakan bahwa pemutusan hubungan kerja akan mengakibatkan pekerja/buruh kehilangan mata 
pencahariannya, yang berarti pula udara (Hasibuan, 2020). Dilansir dari dimulainya masa pengangguran data real time yang dibuat oleh WHO (Sonhaji, 2019). Pemutusan hubungan kerja merupakan sesuatu yang sangat ditakuti oleh para buruh dan pekerja.

Permasalahan pemutusan hubungan kerja mendapatkan tambahan beban lagi sejak masuknya pandemi COVID-19 (Al-Fatih, Ahsany, \& pada tanggal 20 Agustus 2020, terdapat 21,9 juta lebih orang yang terkonfirmasi positif COVID-19 dengan total kematian 775.893 jiwa (World Health Organization, 2020). Di Indonesia, masyarakat yang terinfeksi COVID-19 telah mencapai angka Alamsyah, 2020). COVID-19 144.945 jiwa dengan angka kematian merupakan wabah penyakit yang menyerang seluruh negara pada akhir tahun 2019 hingga saat ini (Disemadi \& Shaleh, 2020). COVID-19 tergolong mencapai 6.346 jiwa (Gugus Tugas Percepatan Penanganan COVID-19, 2020). Hadirnya pandemi COVID-19 tidak hanya berdampak terhadap sektor sebagai virus ribonucleic acid (RNA) kesehatan, namun juga berdampak dengan kandungan alpha, beta, pada sektor ketenagakerjaan di gamma, dan delta genera (Neuman, Indonesia.

2016). Penyebaran COVID-19 Pemerintah Indonesia sebagai dipercaya dimulai dari Wuhan, upaya preventif pencegahan Tiongkok yang diungkap oleh Pusat penyebaran COVID-19 di Indonesia Pengendalian dan Pencegahan Penyakit mengeluarkan Peraturan Pemerintah Tiongkok (CDC). Pandemi yang Nomor 21 Tahun 2020 tentang dimulai dari Tiongkok kini tersebar di Pembatasan Sosial Berskala Besar seluruh dunia, termasuk di Indonesia (PSBB). Akibat adanya PSBB, proses (Einstein, Helmi, \& Ramzy, 2020; produksi, pariwisata, perhotelan, Muhyiddin, 2020; Widayat \& Arifin, maskapai penerbangan dan lain 2020). Masuknya COVID-19 di sebagainya mendapatkan kerugian Indonesia, dimulai awal Maret 2020. yang sangat signifikan (Anwar, 2020). Penyebaran COVID-19 dapat melalui Pada sektor hotel kerugian mencapai “human to human". Bahkan pada saat Rp. 30 triliun, sektor restoran kerugian ini, World Health Organization (WHO) mencapai Rp. 40 triliun bahkan mengeluarkan pernyataan resmi bahwa maskapai penerbangan rugi hingga penyebaran COVID-19 bisa melalui 
US\$ 812 juta atau setara dengan 11,7 triliun (Wahyudi, 2020).

Langkah pemutusan hubungan kerja menjadi jalan yang digunakan pengusaha untuk menghindari kerugian yang signifikan (Juaningsih, 2020). Kementerian Ketenagakerjaan mencatat hingga 31 Juli 2020, angka pemutusan hubungan kerja ataupun dirumahkan mencapai 3,5 juta lebih (CNN Indonesia, 2020b). Padahal upaya kebijakan new normal telah dilakukan oleh pemerintah agar masyarakat dapat bekerja seperti semula dengan memperhatikan protokol kesehatan (Tuwu, 2020). Namun, kebijakan new normal, masih belum bisa memberhentikan pemutusan hubungan kerja secara massal di Indonesia. Melihat meningkatnya jumlah korban pemecatan hubungan kerja secara sepihak di tengah pandemi COVID-19 perlu adanya perlindungan, keadilan, dan kepastian hukum yang jelas bagi buruh dan tenaga kerja.

Mengingat penelitian yang berkaitan dengan pemutusan hubungan kerja telah dilakukan beberapa kali sebelumnya, seperti: 1) Penelitian yang dilakukan oleh Karina Prameswari dan Emi Puasa Handayani yang memfokuskan pada pengaturan pemutusan hubungan kerja antara karyawan dan perusahaan (Prameswari \& Handayani, 2018). Penelitian ini juga menyatakan bahwa akibat hukum yang timbul dari ketidakseimbangan pengaturan pemutusan hubungan kerja mengakibatkan banyaknya demo buruh untuk meminta keadilan terhadap perusahaan; 2) Penelitian yang dilakukan oleh Ropidin dan Setyo Riyanto yang memfokuskan pada dampak pemutusan hubungan kerja pada perusahaan farmasi terkait COVID-19 di Indonesia (Ropidin \& Riyanto, 2020). Penelitian ini memberikan urgensi perlu adanya pemecahan masalah dengan menggunakan dialog dua atau tiga arah dan perlu adanya penyusunan kebijakan untuk melindungi perusahaan dan karyawan; 3) Penelitian yang dilakukan oleh Siti Zulaichah yang memfokuskan pada pemutusan hubungan kerja berdasarkan hukum ketenagakerjaan dan hukum islam (Zulaichah, 2019). Penelitian ini juga memfokuskan terhadap hubungan industrian serta menerangkan bahwa hukum harus memberikan solusi yang tepat agar melindungi berbagai pihak terhindar dari kerugian.

Berdasarkan penelitian yang telah dilakukan sebelumnya, penelitian ini memiliki kesamaan tema yakni 
pemutusan hubungan kerja. Namun, penelitian ini lebih menekankan pada pemutusan hubungan kerja yang dilakukan di tengah pandemi COVID19 secara sepihak. Penelitian ini dikaji berdasarkan perspektif UndangUndang Nomor 13 Tahun 2003 tentang Ketenagakerjaan. Berdasarkan paparan latar belakang diatas, maka fokus kajian pada penelitian ini adalah terkait alasan PHK secara massal dilakukan di tengah pandemi COVID-19 serta analisis hukumnya berdasarkan perspektif Undang-Undang Nomor 13 Tahun 2013 tentang Ketenagakerjaan.

\section{Metode Penelitian}

Penelitian ini merupakan penelitian hukum normatif yang menggunakan teknik studi kepustakaan yang bersumber dari data hukum sekunder dalam mengkaji suatu permasalahan. Data sekunder diperoleh dari literatur hukum yakni perundangundangan, jurnal hukum, buku hukum dan kamus hukum. Dalam metode ini kegunaan utama dari analisa literatur hukum yang diteliti secara kritis dan komprehensif adalah untuk menciptakan suatu argumen yang benar dan melengkapi suatu pernyataan hukum dengan tujuan untuk mencari koherensi hukum.

\section{Hasil dan Pembahasan}

\section{Menelisik Alasan PHK di Tengah} Pandemi COVID-19

Indonesia sebagai negara hukum memiliki tantangan untuk meningkatkan kualitas sumber daya manusia untuk berdaya saing. Peningkatan sumber daya manusia secara terus-menerus dilakukan oleh pemerintah untuk meningkatkan kualitas pekerja. Namun, pemutusan hubungan kerja menjadi sebuah ketakutan yang harus dihadapi oleh pekerja sebagai sebuah ritme kehidupan. Permasalahan pemutusan hubungan kerja bukanlah permasalahan yang bisa dipandang sebelah mata. Pemutusan hubungan kerja secara sepihak oleh perusahaan membuat para pekerja harus kehilangan mata pencahariannya.

$$
\text { Permasalahan pemutusan }
$$
hubungan kerja secara massal bukanlah sebuah cerita yang asing lagi. Hal ini diakibatkan lemahnya perekonomian makro di Indonesia. Indonesia sendiri masih mengandalkan investasi asing untuk menghidupi perekonomian dalam negeri (Febriana \& Muqorobbin, 2014), sehingga apabila terjadi gejolak ekonomi global maka ekonomi dalam negeri dapat mengalami pelemahan secara signifikan. Alasan pemutusan 
hubungan kerja secara massal yang orang (Lokadata, 2018), tahun 2017 terjadi menurut Asosiasi Serikat mencapai 9.800 orang (Lokadata, Pekerja (ASPEK) adalah banyaknya 2018), tahun 2018 mencapai 3.400 kasus upah murah yang terjadi (Lokadata, 2018) dan tahun 2019 diperusahaan, terjadinya kasus union mencapai 3.000 orang (Susanto, 2019). busting (praktik penghentian serikat Namun, di tengah trend positif yang pekerja/serikat buruh di perusahaan) didapatkan, pada tahun 2020, Indonesia (Fuadah \& Soenmi, 2019), dan harus dihadapi pandemi COVID-19 banyaknya tenaga asing yang masuk ke yang menyebabkan angka pemutusan Indonesia (Jazuli, 2018). Alasan lain hubungan kerja meningkat dengan terjadinya pemutusan hubungan kerja tajam pada bulan April mencapai yang dilakukan oleh perusahaan adalah 749.400 orang padahal Indonesia sudah lemahnya tingkat kualitas sumber daya menjalani kebijakan New Normal manusia di Indonesia. Hal ini diungkap (Jayani, 2020).

melalui data World Bank terkait Peningkatan tersebut disebabkan

Grafik 1. Data Jumlah Pemutusan Hubungan Kerja Tahun 2015-2020

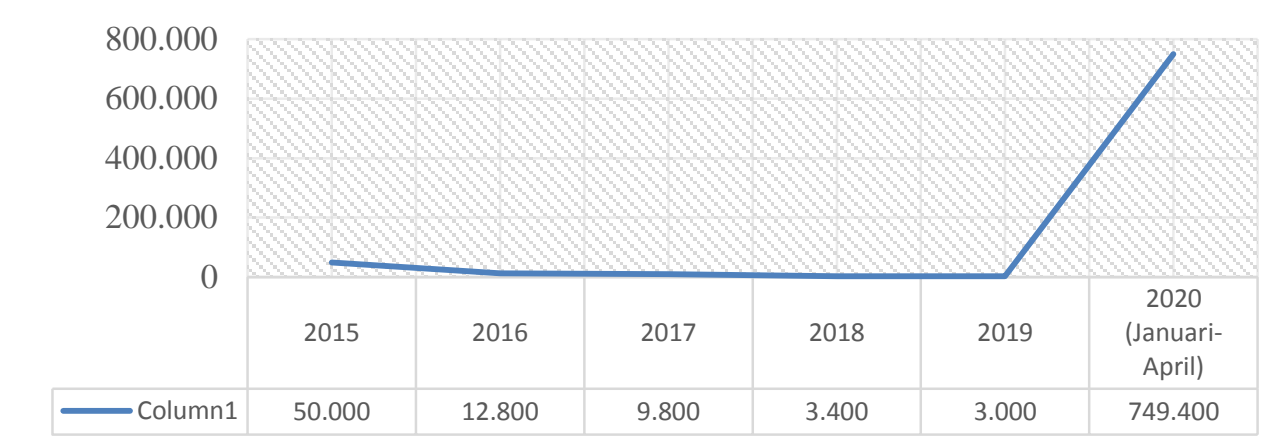

Human Capital Index yang oleh perekonomian Indonesia menyebutkan Human Capital Index mengalami guncangan yang sangat hanya meraih 0,53\% (Victoria, 2019). signifikan. Menurut data dari Badan

Berdasarkan data diatas, angka Pusat Statistika (BPS), pertumbuhan jumlah pemutusan hubungan kerja pada ekonomi di indonesia secara year to tahun 2015 mencapai angka 50,000 year (yoy) menunjukkan penurunan orang (Fajriah, 2018), di tahun pada kuartal I (Q1) 2020 yang berikutnya jumlah pemutusan mencapai kontraksi 2,97\% (Badan hubungan mengalami penurunan. Pusat Statistik, 2020). Penurunan Tahun 2016 mencapai angka 12.800 pertumbuhan ekonomi kembali terjadi 
dengan kontraksi yang lebih besar yaitu $5,32 \%$ pada kuartal II (Q2)(Badan Pusat Statistik, 2020). Penurunan pada kuartal II ini merupakan yang terburuk sejak krisis 1998 dengan pertumbuhan minus 16,5\%. Adapun menurut hitungan quarter to quarter (qoq), pertumbuhan ekonomi Indonesia pada kuarter I 2020 minus 2,41\%. Kontraksi di beberapa komponen menjadi faktor penyebab pertumbuhan ekonomi pada Q2 menurun. Contohnya komponen pengeluaran, konsumsi rumah tangga yang memiliki porsi $57,85 \%$ dari produk domestik bruto (PDB) mengalami pertumbuhan minus hingga 5,51\%, Pembentukan Modal Tetap Bruto (PMTB) yang memiliki jatah $30,61 \%$ dari PDB mengalami pertumbuhan minus 8,61\%, Ekspor yang memiliki porsi $15,69 \%$ dari PDB mengalami pertumbuhan minus $11,66 \%$, impor memiliki porsi $15,52 \%$ mengalami pertumbuhan minus 16,96\%, konsumsi Pemerintah yang memegang porsi $8,67 \%$ dari PDB mengalami pertumbuhan minus $6,9 \%$, dan konsumsi Lembaga non-profit (LNPRT) yang melayani rumah tangga memiliki porsi $1,36 \%$ mengalami pertumbuhan minus 7,76\% (Badan Pusat Statistik, 2020). Selain sektor pengeluaran, BPS menyebutkan sebagian besar sektor lainnya juga mengalami penurunan. Namun, beberapa sektor masih mengalami pertumbuhan yang positif seperti sektor informasi dan komunikasi, jasa keuangan, pertanian, real estate, jasa pendidikan, jasa kesehatan, dan pengadaan air.

Penurunan pertumbuhan ekonomi berimbas pada memburuknya sistem keuangan karena menurunnya penerimaan Negara serta ketidakpastian ekonomi global. Akibatnya perusahaan melakukan pengurangan kegiatan usaha atau penghentian sementara sampai keadaan normal. Pengurangan kegiatan usaha berimplikasi pada pemutusan hubungan kerja (PHK). Alasan yang digunakan perusahaan dalam PHK karyawan antara lain: pertama, ketersediaan bahan baku yang mulai menipis. Hal tersebut dikarenakan lalu lintas yang dihentikan, akibat dari adanya Pembatasan Sosial Berskala Besar (PSBB) yang mengakibatkan penurunan produktivitas industri serta sektor manufaktur harus memangkas $30 \%$, sehingga berpotensi dilakukan pengurangan pekerja untuk menjaga stabilitas arus kas perusahaan (Yunianto, 2020). Kedua, melemahnya Rupiah terhadap Dollar. Perusahaan 
dalam hal ini merasa terbebani karena juta atau turun sebesar 59,96\% angka Rupiah hampir menyentuh nilai dibanding periode yang sama tahun Rp 17.000 per Dollar Amerika Serikat sebelumnya. Penurunan akan semakin (Indonesia, 2020), apabila hal ini terus terjadi akibat penutupan penerbangan berlanjut maka biaya produksi bagi internasional di Indonesia sebagai perusahaan yang menggunakan bahan- upaya pencegahan penyebaran bahan impor akan terus meningkat COVID-19. Keempat, indeks saham tidak sebanding dengan pemasukan gabungan mengalami penurunan drastis perusahaan. Ketiga, pengunjung akibatnya pendapatan Indonesia dari pariwisata Indonesia mengalami ekspor minyak dan indeks saham penurunan sebagai akibat dari social secara kumulatif menurun. Indeks distancing yang diterapkan di berbagai Harga Saham Gabungan (IHSG) Negara untuk menurunkan kurva melemah 2,78\% menjadi 5.006,22 pada penyebaran virus. Hal tersebut perdagangan 3 Agustus 2020 (Utami, berimplikasi pada dirumahkannya 2020). Pelemahan indeks saham ini pekerja pada sektor pariwisata. Badan dibayangi oleh rilis data makro Pusat Statistik (BPS) mengungkapkan ekonomi Indonesia pekan ini. Hal ini pada Januari-April 2020, jumlah mengakibatkan terjadinya tekanan pada kunjungan wisatawan mancanegara ke sektor keuangan Anggaran Pendapatan Indonesia mencapai 2,77 juta dan Belanja Negara (APBN) sehingga kunjungan atau turun sebesar $45,01 \%$ pendapatan Negara dan perusahaandibanding jumlah kunjungan pada perusahaan mengalami penurunan. periode yang sama tahun sebelumnya Kelima, Indonesia pada Juli 2020 yang berjumlah 5,03 juta kunjungan mengalami deflasi sebesar 0,10\% dan (Badan Pusat Statistik, 2020). Bahkan inflasi tahunan mencapai 1,54\% penurunan jumlah kunjungan (Avisena, 2020). Secara garis besar, mancanegara semakin meningkat pada penyebab deflasi pada Juli 2020 Juni 2020 yang mencapai $88,2 \%$ diakibatkan oleh melemahnya dibandingkan periode yang sama tahun konsumsi masyarakat akibat COVIDlalu (Badan Pusat Statistik, 2020). 19 dan pembatasan sosial. Sehingga Sehingga secara kumulatif pada perusahaan harus menurunkan harga Januari-Juni 2020 jumlah kunjungan demi menjaga kestabilan penjualan wisatawan mancanegara mencapai 3,09 meskipun biaya produksi meningkat. 
Beberapa perusahaan juga walaupun tidak ada itikad buruk memutus hubungan kerja dengan padanya alasan force majeure atau keadaan memaksa. Menurut Subekti, force Pasal 1245 KUH Perdata

Tidak ada penggantian biaya, majeure merupakan alasan agar kerugian dan bunga, bila karena terhindar dari kewajiban untuk keadaan memaksa atau karena hal yang membayar ganti rugi (Isradjuningtias, terjadi secara kebetulan, debitur 2018). Beliau melanjutkan syarat terhalang untuk memberikan atau keadaan force majeure yakni keadaan berbuat sesuatu yang diwajibkan, atau itu sendiri diluar dari kekuasaan melakukan suatu perbuatan yang perusahaan dan memaksa serta keadaan terlarang baginya.

tidak pernah diperkirakan sebelumnya Berdasarkan ketentuan yang saat perjanjian dibuat, setidaknya tertuang dalam pasal 1244 dan 1245 resiko yang terjadi tidak dipikul oleh KUH Perdata, terdapat ciri utama yang pekerja yang mengakibatkan mereka dapat menimbulkan keadaanforce harus mengalami pemutusan hubungan majeure adalah (Harnowo, 2020):

kerja. Namun, pengertian force 1. Kejadian yang tidak terduga;

majeure masih belum tertuang secara eksplisit dalam Kitab Undang-Undang Hukum Perdata. Disisi lain terdapat 2 pasal yang sering menjadi acuan dalam pengkajian force majeure di Indonesia, yakni Pasal 1244 dan Pasal 1245 KUH Perdata, yang tertulis sebagai berikut:

\section{Pasal 1244 KUH Perdata}

Debitur harus dihukum untuk mengganti biaya, kerugian dan bunga, bila ia tak dapat membuktikan bahwa tidak dilaksanakannya perikatan itu atau tidak tepatnya waktu dalam melaksanakan perikatan itu disebabkan oleh suatu hal yang tak terduga, yang tak dapat dipertanggungkan kepadanya,

2 $\begin{array}{lr}\text { Terdapat halangan yang } \\ \text { menyebabkan } & \begin{array}{r}\text { sebuah } \\ \text { prestasi/pekerjaan tidak dapat } \\ \text { berjalan; }\end{array}\end{array}$

3. Ketidakmampuan tersebut bukan hasil kesalahan debitur; dan

4. Ketidakmampuan yang terjadi tidak boleh dibebankan risiko terhadap pihak debitur.

Luasnya makna dari situasi force majeure, biasanya para pihak sebagai wujud kepastian hukum mencantumkan klausula dengan daftar peristiwa yang dapat menjadi alasan force majeure dalam perjanjian mereka. Force majeure event means the occurrence of 
an event of (Dinar \& Budiartha, 2020): (a) war (whether declared or not), armed conflict or the serious threat of same (including but not limited to hostile attack, blockade, military embargo), hostilities, invasion, act of a foreign enemy, extensive military mobilisation; (b) civil war, riot rebellion and revolution, military or usurped power, insurrection, civil commotion or disorder, mob violence, act of civil disobedience; (c) act of terrorism, sabotage or piracy; (d) act of authority whether lawful or unlawful, compliance with any law or governmental order, rule, regulation or direction, curfew restriction, expropriation, compulsory acquisition, seizure of works, requisition, nationalisation; (e) act of God, plague, epidemic, natural disaster such as but not limited to violent storm, cyclone, typhoon, hurricane, tornado, blizzard, earthquake, volcanic activity, landslide, tidal wave, tsunami, flood, damage or destruction by lightning, drought; (f) explosion, fire, destruction of machines, equipment, factories and of any kind of installation, prolonged break-down of transport, telecommunication or electric current; (g) general labour disturbance such as but not limited to boycott, strike and lock-out, go-slow, occupation of factories and premises.

Disisi lain dalam pasal 47 aat (1) huruf j Undang-Undang Nomor 2 Tahun 2017 tentang Jasa Konstruksi mengungkapkan makna force majeure dapat diartikan sebagai keadaan yang diluar kemauan dan merugikan salah satu pihak. Keadaan memaksa tersebut meliputi (Isradjuningtias, 2018):

1. Keadaan memaksa yang bersifat mutlak (absolut), yakni keadaan dimana para pihak tidak bisa memulai atau melanjutkan hak dan kewajibannya sesuai perjanjian; dan

2. Keadaan memaksa yang bersifat relatif, yakni keadaan dimana para pihak masih bisa memulai dan melanjutkan hak dan kewajibannya.

Apabila dihubungkan dengan pandemi COVID-19 ini, dapat dikatakan sebagai sebuah peristiwa yang tidak terduga saat perjanjian. Sehingga jika ada perjanjian yang dibuat pada saat wabah menyerang Indonesia dan mengakibatkan pemutusan hubungan kerja tidak dapat dijadikan alasan force majeure. Terlebih dalam Undang-Undang Ketenagakerjaan Nomor 13 Tahun 2003 Pasal 164 Ayat (3) syarat pemutusan hubungan kerja kepada para pekerja adalah apabila perusahaan 
mengalami penurunan pendapatan atau kerugian berturut-turut selama 2 tahun terakhir bukan karena keadaan memaksa atau force majeure melainkan karena efisiensi. COVID-19 tentu saja belum mencapai 2 tahun lamanya sehingga alasan PHK dengan menggunakan force majeure tidak dapat dibenarkan. COVID-19 merupakan suatu keadaan yang tidak terduga pada saat perjanjian kerja dibuat, sehingga apabila perjanjian yang dibuat pada saat wabah sedang menjalar dan menjangkit PHK maka tidak dapat digunakan alasan force majeure. Dengan demikian, perlu adanya perlindungan terhadap tenaga kerja sehingga mampu menjadi hakhak dasar pekerja sebagai wujud menciptakan kesejahteraan pekerja dengan tetap mementingkan kepentingan perusahaan (Juaningsih, 2020).

\section{Analisis Pemutusan Hubungan}

Kerja Berdasarkan Undang-Undang Ketenagakerjaan di Tengah Pandemi COVID-19

Pandemi COVID-19 dijadikan alasan pembenaran kesewenangwenangan perusahaan terhadap pekerja (Syafrida, Safrizal, \& Suryani, 2020). Sebagai manusia, pekerja berhak mendapatkan perlakuan yang adil dan layak dalam hubungan kerja. Pekerja berhak mendapatkan perlindungan terhadap pemutusan hubungan kerja yang sewenang-wenang (Hunnicutt, 1988). Pemutusan hubungan kerja sepihak yang dilakukan perusahaan membawa dampak semakin meningkatnya pengangguran yang ada di Indonesia (Kennedy, 2020). Pemutusan hubungan kerja massal yang dilakukan di tengah pandemi tanpa adanya pesangon kepada pekerja mencerminkan adanya pelanggaran hak asasi manusia (Mardiansyah, 2020). Hal ini terungkap oleh Peneliti Lembaga Ilmu Pengetahuan Indonesia (LIPI) yang melakukan survei dengan 2.160 responden periode 24 April- 2 Mei 2020, sebanyak 3,8\% tenaga kerja terkena pemutusan hubungan kerja tanpa mendapatkan pesangon. Dalam hal ini pemutusan hubungan kerja massal tanpa adanya pesangon melanggar hak untuk bekerja dan mendapat upah yang telah diatur dalam Pasal 28D Ayat 2 Undang-Undang Dasar Negara Republik Indonesia Tahun 1945 dan Konvensi ILO Nomor 100 serta Pasal 156 Undang-Undang Ketenagakerjaan

Pemutusan hubungan kerja tidak serta merta dapat dilakukan perusahaan tanpa mengikuti peraturan yang 
berlaku. Dalam Undang-Undang Tenaga Kerja Nomor 13 Tahun 2003 dengan jelas disebutkan bahwa sebabsebab Pemutusan hubungan kerja antara lain:

1. Adanya kesalahan berat yang dilakukan oleh pekerja berupa pencurian, penipuan, penggelapan barang, narkotika, mabuk, minum minuman keras, bertindak tidak baik terhadap sesama pekerja, membujuk sesama pekerja untuk melakukan suatu hal yang bertentangan terhadap undang-undang, sengaja merusak barang perusahaan sehingga menimbulkan kerugian (Pasal 158);

2. Pekerja melanggar kesepakatan pada perjanjian kerja (Pasal 161);

3. Pekerja mengundurkan diri dari suatu perusahaan (Pasal 162);

4. Pengusaha dapat melakukan pemutusan hubungan kerja terhadap pekerja ketika perusahaan mengalami kerugian selama 2 tahun berturut-turut hingga menyebabkan harus ditutupnya perusahaan (Pasal 164);

5. Perusahaan dapat melakukan pemutusan hubungan kerja terhadap pekerja ketika perusahaan mengalami pailit (Pasal 165);
6. Pemutusan hubungan kerja dapat dilakukan ketika pekerja telah meninggal dunia (Pasal 166);

7. Pemutusan hubungan kerja dapat dilakukan ketika pekerja telah memasuki usia pensiun. (Pasal 167); dan

8. Mangkirnya pekerja selama 5 tahun (Pasal 168).

Dalam UU Ketenagakerjaan, ketika seorang pengusaha melakukan pemutusan hubungan kerja terhadap karyawannya maka pengusaha wajib memenuhi hak-hak karyawan yang menjadi korban pemutusan hubungan kerja yang diatur dalam Pasal 156 yakni :

1. Uang Pesangon, yakni pembayaran berupa uang dari pengusaha kepada pekerja sebagai akibat dari berakhirnya hubungan kerja. Penghitungan besaran uang pesangon didasarkan pada: pertama, masa kerja kurang dari 1 tahun, satu bulan upah. Kedua, masa kerja 1 tahun atau lebih tapi kurang dari 2 tahun, 2 bulan upah. Ketiga, masa kerja 2 tahun atau lebih tapi kurang dari 3 tahun, 3 bulan upah. Keempat, masa kerja 3 tahun atau lebih tetapi kurang dari 4 tahun, 4 bulan upah. Kelima, masa kerja 4 tahun atau lebih tetapi kurang dari 5 tahun, 5 
bulan upah. Keenam, masa kerja 5 tahun atau lebih, tetapi kurang dari 6 tahun, 6 bulan upah. Ketujuh, masa kerja 6 tahun atau lebih tetapi kurang dari 7 tahun, 7 bulan upah. Kedelapan, masa kerja 7 (tujuh) tahun atau lebih tetapi kurang dari 8 tahun, 8 bulan upah. Terakhir, masa kerja 8 tahun atau lebih, 9 bulan upah;

2. Uang Penghargaan Masa Kerja, yakni uang yang diberikan kepada pekerja sebagai apresiasi terhadap pekerja yang dikaitkan dengan lamanya masa kerja pekerja (Khakim, 2014). Perhitungan upah penghargaan masa kerja didasarkan pada: pertama, masa kerja 3 tahun atau lebih tetapi kurang dari 6 tahun, 2 bulan upah. Kedua, masa kerja 6 tahun atau lebih tetapi kurang dari 9 tahun, 3 bulan upah. Ketiga, masa kerja 9 tahun atau lebih tetapi kurang dari 12 tahun, 4 bulan upah. Keempat, masa kerja 12 tahun atau lebih tetapi kurang dari 15 tahun, 5 bulan upah. Kelima, masa kerja 15 tahun atau lebih tetapi kurang dari 18 tahun, 6 bulan upah. Keenam, masa kerja 18 tahun atau lebih tetapi kurang dari 21 tahun, 7 bulan upah. Ketujuh, masa kerja 21 tahun atau lebih tetapi kurang dari 24 tahun, 8 bulan upah. Kedelapan, masa kerja 24 tahun atau lebih, 10 bulan upah; dan

3. Uang Penggantian Hak Yang Seharusnya Diterima, yakni uang pembayaran dari pengusaha kepada pekerja sebagai pengganti waktu istirahat tahunan, istirahat panjang, biaya perjalanan dari tempat dimana pekerja diterima bekerja, fasilitas pengobatan, fasilitas perumahan, dan lainnya sebagai akibat dari penghentian hubungan kerja (Khakim, 2014). Hal yang perlu diperhatikan dalam pemberian uang penggantian hak yang seharusnya diterima adalah: pertama. Cuti tahunan yang belum diambil dan belum gugur. Kedua, biaya atau ongkos pulang untuk pekerja dan keluarganya ketempat dimana pekerja diterima bekerja. Ketiga, penggantian perumahan serta pengobatan dan perawatan $15 \%$ dari uang pesangon dan/atau uang penghargaan masa kerja bagi yang memenuhi syarat. Keempat, hal-hal yang lain yang ditetapkan dalam perjanjian kerja, peraturan perusahaan atau perjanjian kerja bersama.

Tanpa terpenuhinya persyaratan pemutusan hubungan kerja secara 
massal maka pemutusan hubungan kerja tidak dapat dilakukan, ditambah perusahaan yang tidak membayarkan hak-hak pekerja yang di pemutusan hubungan kerja maka perusahaan telah melakukan beberapa pelanggaran (Inayah \& Surisman, 2020). Apalagi, pemutusan hubungan kerja membawa dampak psikologis, ekonomi, dan finansial. Pengaruh pemutusan hubungan kerja dalam kehidupan seperti:

\section{Pemutusan hubungan kerja menyebabkan pekerja kehilangan mata pencaharian;}

2. Untuk mencari pekerjaan yang baru sebagai gantinya harus banyak mengeluarkan biaya;

3. Kehilangan biaya hidup untuk diri sendiri dan keluarganya sebelum mendapatkan pekerjaan yang baru

Berkaitan dengan banyaknya dampak pemutusan hubungan kerja dalam UU Ketenagakerjaan pada Pasal 151 Ayat 1 memberikan amanat agar pengusaha berusaha tidak melakukan pemutusan hubungan kerja sehingga terdapat batasan-batasan bagi pengusaha yang hendak melakukan pemutusan hubungan kerja. Alasanalasan yang melarang adanya pemutusan hubungan kerja antara lain:
1. Pekerja/Buruh berhalangan hadir karena sakit menurut keterangan dokter selama waktu tidak melampaui 12 bulan secara terusmenerus;

2. Pekerja/Buruh berhalangan menjalankan pekerjaannya karena memenuhi kewajiban terhadap Negara sesuai dengan peraturan perundang-undangan yang berlaku;

3. Pekerja/Buruh menjalankan perintah ibadah yang di perintahkan agamanya;

4. Pekerja/Buruh menikah;

5. Pekerja/Buruh perempuan hamil, melahirkan, gugur kandungan, atau menyusui bayinya;

6. Pekerja/Buruh mempunyai pertalian darah dan/atau ikatan perkawinan dengan Pekerja/Buruh lainnya di dalam satu perusahaan, kecuali telah diatur dalam perjanjian kerja, peraturan perusahaan, atau perjanjian kerja bersama;

7. Pekerja/Buruh mendirikan, menjadi anggota dan/atau pengurus serikat Pekerja/Buruh Pekerja, Pekerja/Buruh melakukan kegiatan serikat Pekerja/Buruh Pekerja diluar jam kerja, atau di dalam jam kerja atas dasar kesepakatan pengusaha, atau berdasarkan ketentuan yang diatur dalam perjanjian kerja, 
peraturan perusahaan, atau massal saat negara mengalami krisis perjanjian kerja bersama;

perekonomian bukanlah suatu langkah

8. Pekerja/Buruh mengadukan pengusaha kepada yang berwajib mengenai perbuatan pengusaha melakukan tindak pidana kejahatan;

9. Karena perbedaan paham, agama, aliran politik, suku, warna kulit, golongan, jenis kelamin, kondisi fisik, atau status perkawinan; dan

10. Pekerja/Buruh dalam keadaan cacat tetap, sakit akibat kecelakaan kerja, atau sakit karena hubungan kerja yang menurut surat keterangan dokter yang jangka waktu penyembuhannya belum dapat dipastikan.

Menilik pada pasal 151 ayat (1)

UU Ketenagakerjaan, menyebutkan bahwa Pengusaha, pekerja/buruh, serikat pekerja/serikat buruh, dan pemerintah, harus mengupayakan agar tidak terjadi pemutusan hubungan kerja terhadap pekerja. Pada pasal ini pun mengamanatkan agar pemerintah, pengusaha, buruh dan serikat buruh saling bahu-membahu menghindari pemutusan hubungan kerja untuk mengentaskan permasalahan perekonomian pada krisis ekonomi negara agar tidak berimbas pada keberlanjutan hidup pekerja Indonesia. Pemutusan hubungan kerja secara yang tepat dalam mengatasi suatu permasalahan apalagi dilakukan secara sepihak. Ketika negara dilanda pandemi, yang membuat ketidakstabilan perekonomian, seyogianya pemerintah dan pengusaha mengupayakan agar tidak terjadi pemutusan hubungan kerja dengan dihadirkannya solusi yang mengacu pada Surat Edaran Menteri Tenaga Kerja dan Transmigrasi SE907/MEN/PHI-PPHI/X/2004 yang tetap berdasar pada SE Menaker 3/2020 tentang Perlindungan Pekerja/Buruh dan Kelangsungan Usaha dalam Rangka Pencegahan dan Penanggulangan COVID-19. Solusi tersebut yakni mengurangi upah dan fasilitas pekerja tingkat atas seperti manajer dan staf perusahaan, mengurangi shift, membatasi dan menghapuskan kerja lembur, mengurangi jam kerja, meliburkan dan merumahkan pekerja secara bergilir untuk sementara waktu, tidak memperpanjang masa kontrak pekerja yang sudah habis masa kontraknya, dan memberikan pensiun kepada pekerja yang telah memasuki usia lanjut dan telah memenuhi syarat pensiun. 
Jika berbagai upaya telah Kesimpulan

dilakukan untuk menghindari

Masuknya pandemi COVID-19 di

pemutusan hubungan kerja dan

Indonesia

mengakibatkan

pemutusan hubungan kerja harus perekonomian bertumbuh negatif.

dilakukan, maka pemutusan hubungan Pertumbuhan negatif tersebut diikuti

kerja tidak boleh dilakukan secara oleh banyaknya perusahaan yang

sepihak. Langkah selanjutnya yang melakukan pemutusan hubungan kerja

dapat dilakukan adalah upaya terhadap karyawan/buruh. Berdasarkan perundingan antara pengusaha dan penelitian ini, banyaknya kasus pekerja atau serikat pekerja. Menurut pemutusan hubungan kerja yang pasal 151 ayat 3 apabila perundingan dilakukan perusahaan menyalahi aturan tersebut belum juga menghasilkan yang telah dibuat. Dalam Undangpersetujuan, pengusaha dapat Undang Nomor 13 Tahun 2013 tentang melakukan pemutusan hubungan kerja Ketenagakerjaan pasal 151 secara jelas setelah mendapatkan penetapan dari diungkapkan bahwa pengusaha, lembaga penyelesaian perselisihan pemerintah dan karyawan wajib hubungan industrial. Mengenai hal ini mengusahakan agar tidak terjadi sudah diatur di dalam Undang-Undang pemutusan hubungan kerja. Terlebih Nomor 2 Tahun 2004 tentang banyaknya alasan perusahaan Penyelesaian Perselisihan Hubungan melakukan pemutusan hubungan kerja Industrial. Namun, apabila pemutusan seperti force majeure dan kerugian hubungan kerja dilakukan tanpa yang sangat signifikan. Padahal dalam penetapan dari lembaga penyelesaian Pasal $164 \quad$ Undang-Undang perselisihan hubungan industrial maka Ketenagakerjaan menyebutkan bahwa batal demi hukum sehingga pemutusan pengusaha dapat melakukan pemutusan hubungan kerja dianggap tidak pernah hubungan kerja terhadap pekerja ketika ada. Selama penetapan dari lembaga perusahaan mengalami kerugian penyelesaian perselisihan hubungan selama 2 tahun berturut-turut hingga industrial belum keluar, pengusaha dan menyebabkan harus ditutupnya pekerja tetap harus menunaikan perusahaan. Hal ini menjadi polemik, kewajibannya masing-masing. karena kehadiran COVID-19 belum sampai 2 tahun atau lebih tepatnya 
masih 5 bulan sejak diumumkannya COVID-19 pada awal Maret 2020.

Berdasarkan hasil penelitian ini, kebijakan pengusaha untuk melakukan pemutusan hubungan kerja di tengah pandemi COVID-19 bukan merupakan win-win solution saat ini. Padahal pemerintah sudah melakukan kebijakan New Normal dengan protokol kesehatan, sehingga perusahaan, pabrik dan sebagainya masih bisa berproduksi. Perusahaan bisa saja merumahkan para pekerja, tanpa melakukan pemutusan hubungan kerja. Karena secara hakikatnya, ketika perusahaan melakukan pemutusan hubungan kerja maka perusahaan dan karyawan sudah tidak memiliki hubungan lagi. Disisi lain, ketika para karyawan, buruh dan tenaga kerja lainnya dirumahkan, mereka masih mampu untuk bekerja kembali saat situasi sudah aman atau tetap bekerja dengan protokol kesehatan.

\section{Daftar Pustaka}

Al-Fatih, S., Ahsany, F., \& Alamsyah, A. F. (2020). LEGAL PROTECTION OF LABOR RIGHTS DURING THE CORONAVIRUS DISEASE 2019 (COVID-19) PANDEMIC. Jurnal Pembaharuan Hukum, 7(2), 100115. https://doi.org/10.26532/jph.v7i2. 10975
Anwar, M. (2020). Dilema PHK dan Potong Gaji Pekerja Di Tengah Covid-19. 'Adalah: Buletin Hukum \& Keadilan, 4(1), 173178.

https://doi.org/10.15408/adalah.v4 i1.15752

Avisena, M. I. R. (2020). Deflasi 0,10\% Pada Juli 2020, BPS: Daya Beli Harus Ditingkatkan. Retrieved July 20, 2020, from Media Indonesia website: https://mediaindonesia.com/read/d etail/333562-deflasi-010-padajuli-2020-bps-daya-beli-harusditingkatkan

Badan Pusat Statistik. (2020a). Perkembangan Pariwisata dan Transportasi Nasional April 2020. Jakarta, Indonesia.

Badan Pusat Statistik. (2020b). Perkembangan Pariwisata dan Transportasi Nasional Juni 2020. Retrieved from Berita Resmi Statistik website: https://ekbis.sindonews.com/berita /1365790/34/kspi-sebut-ada-4gelombang-phk-besar-besaransejak-2015

Badan Pusat Statistik. (2020c). Pertumbuhan Ekonomi Indonesia Triwulan I-2020. Jakarta, Indonesia.

Badan Pusat Statistik. (2020d). Pertumbuhan Ekonomi Indonesia Triwulan II-2020. Jakarta, Indonesia.

CNN Indonesia. (2020a). Imbas Corona, Kurs Rupiah Kian Dekati Rp17 Ribu per Dolar AS. Retrieved August 13, 2020, from https://www.cnnindonesia.com/ek onomi/20200323120743-78486008/imbas-corona-kursrupiah-kian-dekati-rp17-ribu-per- 
dolar-as

CNN Indonesia. (2020b). Pekerja Dirumahkan dan Kena PHK Akibat Corona Capai 3,05 Juta. Retrieved August 21, 2020, from https://www.cnnindonesia.com/ek onomi/20200720114203-92526610/pekerja-dirumahkan-dankena-phk-akibat-corona-capai305-juta

Dinar, I. G. A. A. G. P., \& Budiartha, I. N. P. (2020). A Comprehensive Force Majeure Model Clause in Corporate Transactions in Indonesia. Sociological Jurisprudence Journal, 3(2), 138144.

https://doi.org/10.22225/scj.3.2.19 01.138-144

Disemadi, H. S., \& Shaleh, A. I. (2020). Banking credit restructuring policy amid COVID19 pandemic in Indonesia. Jurnal Inovasi Ekonomi, 3(3). https://doi.org/https://doi.org/10.2 2219/jiko.v5i3.11790

Einstein, T., Helmi, M. I., \& Ramzy, A. (2020). Kedudukan Peraturan Pemerintah Pengganti UndangUndang Nomor 1 Tahun 2020 Terkait Covid-19 Perspektif Ilmu Perundang-Undangan. SALAM: Jurnal Sosial Dan Budaya Syar-I, 7(7), 595-612. https://doi.org/10.15408/sjsbs.v7i7 .15826

Fajriah, L. R. (2018). KSPI Sebut Ada 4 Gelombang PHK Besar-besaran Sejak 2015. Retrieved August 1, 2020, from Sindonews.com website:

https://ekbis.sindonews.com/berita /1365790/34/kspi-sebut-ada-4gelombang-phk-besar-besaransejak-2015
Febriana, A., \& Muqorobbin, M. (2014). Investasi Asing Langsung Di Indonesia Dan Faktor Faktor Yang Mempengaruhinya. Jurnal Ekonomi \& Studi Pembangunan., 15(2), 109-117. https://doi.org/10.18196/jesp.15.2. 1221

Fuadah, A. F., \& Soenmi, L. (2019). Menghancurkan Solidaritas Praktek Pemberangusan Serikat Buruh di Indonesia 2014-2019. Jakasrta: LOKATARU FOUNDATION.

Gugus Tugas Percepatan Penanganan COVID-19. (2020). Peta Sebaran. Retrieved July 15, 2020, from https://covid19.go.id/peta-sebaran

Harnowo, T. (2020). Wabah Corona sebagai Alasan Force Majeur dalam Perjanjian. Retrieved August 5, 2020, from HukumOnline.com website: https://www.hukumonline.com/kli nik/detail/lt5e81ae9a6fc45/wabahcorona-sebagai-alasan-forcemajeur-dalam-perjanjian/

Hasibuan, L. (2020). WHO Sebut Covid Menyebar di Udara, Catat Panduan Barunya. Retrieved July 15, 2020, from https://www.cnbcindonesia.com/te ch/20200712091017-37171991/who-sebut-covidmenyebar-di-udara-catat-panduanbarunya

Hendrastomo, G. (2010). Menakar Kesejahteraan Buruh: Memperjuangkan Kesejahteraan Buruh diantara Kepentingan Negara dan Korporasi. Informasi, $36(2)$, $1-17$. https://doi.org/10.21831/informasi .v2i2.6205

Hunnicutt, B. (1988). Work Without 
End: Abandoning Shorter Hours for the Right to Work. New York: Temple University Press.

Inayah, \& Surisman. (2020). Work Termination During The Covid-19 Pandemic in The Perspective of Positive Law in Indonesia. Legal Standing: Jurnal Ilmu Hukum, 4(1), 247-254.

Isradjuningtias, A. C. (2018). Force Majeure (Overmacht) Dalam Hukum Kontrak (Perjanjian) Indonesia. Veritas et Justitia, 1(1), 136-158.

https://doi.org/10.25123/vej.1420

Jayani, D. H. (2020). Wabah PHK akibat COVID-19. Retrieved August 12, 2020, from Katadata website:

https://katadata.co.id/ariayudhistir a/infografik/5e9a66d0e897f/waba h-phk-akibat-covid-19

Jazuli, A. (2018). Eksistensi Tenaga Kerja Asing di Indonesia dalam Perspektif Hukum Keimigrasian. Jurnal Ilmiah Kebijakan Hukum, 12(1), 89-105. https://doi.org/10.30641/kebijakan .2018.V12.89-105

Juaningsih, I. N. (2020). Analisis Kebijakan PHK Bagi Para Pekerja Pada Masa Pandemi Covid-19 di Indonesia. 'Adalah: Buletin Hukum \& Keadilan, 4(1), 189196.

https://doi.org/10.15408/adalah.v4 i1.15764

Kennedy, R. (2020). Legal Discourse on Manpower During COVID-19 Outbreak. Law Reform, 16(1), 70 86.

https://doi.org/doi.org/10.14710/lr. v16i1.30306

Lokadata. (2018). Angka PHK di
Indonesia, 2014-2018. Retrieved August 1, 2020, from https://lokadata.beritagar.id/chart/ preview/angka-phk-di-indonesia2014-2018-1581482895

Mardiansyah, D. (2020). The Corona Virus and Labor Rights Issues: How Do Workers Get Their Rights? The Indonesian Journal of International Clinical Legal Education, 2(2), 129-146. https://doi.org/doi.org/10.15294/iji cle.v2i2.38328

Muabezi, Z. A. (2017). Negara Berdasarkan Hukum (Rechtsstaats) Bukan Kekuasaan (Machtsstaat). Jurnal Hukum Dan Peradilan, 6(3), 421-446. https://doi.org/10.25216/jhp.6.3.2 017.421-446

Muhyiddin. (2020). Covid-19, New Normal, dan Perencanaan Pembangunan di Indonesia. Jurnal Perencanaan Pembangunan: The Indonesian Journal of Development Planning, 4(2), 240252.

https://doi.org/10.36574/jpp.v4i2. 118

Neuman, B. W. (2016). Bioinformatics and functional analyses of coronavirus nonstructural proteins involved in the formation of replicative organelles. Antiviral Research, 235, 97-107. https://doi.org/10.1016/j.antiviral. 2016.10.005

Prameswari, K., \& Handayani, E. M. I. P. (2018). Pengaturan Pemutusan Hubungan Kerja Antara Karyawan Dengan Perusahaan. Mizan: Jurnal Ilmu Hukum, 8(1), 99-112. https://doi.org/10.32503/mizan.v7i 1.923 
Ropidin, \& Riyanto, S. (2020).

DAMPAK PEMUTUSAN

HUBUNGAN KERJA PADA PERUSAHAAN FARMASI

TERKAIT COVID-19 DI

INDONESIA. Jurnal Syntax

Transformation, 1(5), 167-174. https://doi.org/10.46799/jurnal\%2

0syntax\%20transformation.v1i5.6 3

Sonhaji. (2019). Analisis Yuridis Pemutusan Hubungan Kerja Akibat Kesalahan Berat Pekerja. Adminitrative Law \& Governance Journal, 2(1), 60-78. https://doi.org/10.14710/alj.v2i1.6 $0-78$

Susanto, V. Y. (2019). Serikat Pekerja: Ada 3.000 perkerja kena PHK sejak awal tahun, tanpa pembekalan.

Syafrida, Safrizal, \& Suryani, R. (2020). PEMUTUSAN HUBUNGAN KERJA MASA PANDEMI COVID- 19 PERUSAHAAN TERANCAM DAPAT DIPAILITKAN. Pamulang Law Review, 3(1), 1930.

https://doi.org/dx.doi.org/10.3249 3/palrev.v3i1.6532

Tuwu, D. (2020). KEBIJAKAN PEMERINTAH DALAM PENANGANAN PANDEMI COVID-19. Journal Publicuho, $3(2)$, 267-278. https://doi.org/10.35817/jpu.v3i2. 12535

Utami, D. N. (2020). IHSG Diproyeksi Bergerak Konsolidasi Melemah, Ini Penyebabnya. Retrieved August 21, 2020, from Bisnis.com website:

https://market.bisnis.com/read/202 00809/189/1276826/ihsgdiproyeksi-bergerak-konsolidasi- melemah-ini-penyebabnya

Victoria, A. O. (2019). Bappenas: Kualitas SDM Indonesia Masih Ketinggalan Jauh dari Vietnam. Retrieved August 13, 2020, from Katadata website: https://katadata.co.id/agustiyanti/fi nansial/5e9a50395709c/bappenaskualitas-sdm-indonesia-masihketinggalan-jauh-dari-vietnam

Wahyudi, E. (2020). PHRI: Sektor Pariwisata Rugi Rp 85,7 Triliun Akibat Pandemi. Retrieved August 18, 2020, from Tempo.co website:

https://bisnis.tempo.co/read/13650 55/phri-sektor-pariwisata-rugi-rp857-triliun-akibat-pandemi

Widayat, \& Arifin, Z. (2020). Attitude and Behavior to Eating in the Time of COVID-19; A Case Study of Adolescent Consumer in Indonesia. Jurnal Inovasi Ekonomi, 5(3), 37-44. https://doi.org/10.22219/jiko.v0i0. 11866

World Health Organization. (2020). Coronavirus Disease (COVID19). Retrieved July 15, 2020, from https://www.who.int/emergencies/ diseases/novel-coronavirus2019? gclid=CjwKCAjwr7X4BRA 4EiwAUXjbt3zxrwBNBMWOHd mnQXZP6XTaXoth43jQuP3eWK an7lIAai0NPdgI4hoCm0EQAvD_ BwE

Yunianto, T. K. (2020). Pembatasan Sosial Skala Besar, Sektor Manufaktur Pangkas Produksi 30\%. Retrieved August 9, 2020, from Katadata website: https://katadata.co.id/ekarina/berit a/5e9a41f74b260/pembatasansosial-skala-besar-sektormanufaktur-pangkas-produksi-30 
Zulaichah, S. (2019). Pemutusan Hubungan Kerja Sepihak Ditinjau dari Hukum Ketenagakerjaan dan Hukum Islam. Journal of Islamic Business Law, 3(4), 1-12. Retrieved from http://urj.uinmalang.ac.id/index.php/jibl/article /view/424 